\title{
Analisis Perbandingan KDRT oleh Suami dan Istri di Jawa Barat
}

\author{
PUDJI MULJONO \\ Fakultas Ekologi Manusia, Institut Pertanian Bogor, Jl Kamper Kampus Darmaga, Bogor 16680 \\ email: pudjimuljono@gmail.com
}

\begin{abstract}
The phenomenon of domestic violence cases trend to increase in Indonesia, whether committed by the husband or the wife. This study has a high urgency because it is expected to provide relevant solutions to the social problems. A survey of domestic violence-prone families conducted in two regencies, i.e. Cianjur and Indramayu Regency. The sample was selected from two districts and 4 villages with the number of respondents 178 families, each consisting of a husband and wife. Data on domestic violence were analyzed and compared with the test T-test. The results showed that domestic violence committed husband to wife and vice versa wife against husband, both in Cianjur and Indramayu Regency is included in the low category. Necessary to develop a model of intervention to strengthen local institutions that can support a family protection against domestic violence at the community level, for example through Posdaya (Family Empowerment Post).
\end{abstract}

Keywords: domestic violence, west java

\begin{abstract}
Abstrak. Fenomena kasus KDRT cenderung semakin meningkat di Indonesia, baik yang dilakukan pihak suami maupun pihak istri. Penelitian ini memiliki urgensi yang tinggi karena diharapkan dapat memberikan solusi terkait dengan masalah sosial tersebut. Survei terhadap keluarga rawan KDRT dilaksanakan di 2 kabupaten, yaitu Kabupaten Cianjur dan Kabupaten Indramayu. Sampel dipilih dari 2 kecamatan dan 4 desa dengan jumlah responden 178 keluarga, masing-masing terdiri dari suami dan istri. Data tentang kekerasan dalam rumah tangga dianalisis dan dibandingkan dengan uji T-test. Hasil penelitian menunjukkan bahwa KDRT yang dilakukan suami terhadap istri dan sebaliknya istri terhadap suami, baik di Kabupaten Cianjur dan Kabupaten Indramayu termasuk dalam kategori rendah. Perlu disusun model intervensi untuk menguatkan kelembagaan lokal yang dapat mendukung perlindungan keluarga terhadap KDRT di tingkat komunitas, misalnya melalui Posdaya (Pos Pemberdayaan Keluarga).
\end{abstract}

Kata kunci: KDRT, kekerasan dalam rumah tangga, jawa barat

\section{Pendahuluan}

Salah satu permasalahan yang dihadapi Bangsa Indonesia saat ini adalah jumlah penduduk miskin yang relatif tinggi, yakni sekitar $12,9 \%$ dari jumlah total penduduk. Dampak dari kemiskinan ini mengakibatkan permasalahan yang lebih kompleks di bidang sosial kemasyarakatan seperti meningkatnya tindak kekerasan dalam rumah tangga dan masyarakat, kasus trafficking, serta masalah sosial lainnya (Kusantati dan Widiaty, 2009:1).

Kasus kekerasan dalam rumah tangga (KDRT) di Indonesia terus mengalami peningkatan setiap tahunnya. Peningkatan itu disebabkan oleh berbagai faktor. Berdasarkan data Komnas Perempuan, pada tahun 2012, sedikitnya ada 8.315 kasus dalam setahun. Jumlah itu mengalami peningkatan pada tahun 2013 yang mencapai 11.719 kasus, atau naik 3.404 kasus dari tahun sebelumnya. Peningkatan kasus itu disebabkan karena banyak faktor. Salah satunya dari dalam keluarga itu sendiri, seperti masalah-masalah pribadi, dan antara anggota keluarga. Faktor lainnya adalah, masih adanya rasa memiliki sepenuhnya yang tertanam pada jiwa kaum laki-laki.

Received: 12 Maret 2015, Revision: 09 Juni 2015, Accepted: 25 Desember 2015

Print ISSN: 0215-8175; Online ISSN: 2303-2499. Copyright@2015. Published by Pusat Penerbitan Universitas (P2U) LPPM Unisba Terakreditasi SK Kemendikbud, No.040/P/2014, berlaku 18-02-2014 s.d 18-02-2019 
Rasa memiliki sepenuhnya itu memicu kaum laki-laki untuk meminta istrinya melakukan hal yang sesuai dengan kemauan mereka (Setiadi, 2014: 1).

Berbagai upaya perlindungan kelompok masyarakat yang rentan kekerasan dalam rumahtangga (KDRT) telah dilakukan di Indonesia, baik melalui pendekatan hukum atau pun pendekatan pekerjaan sosial (Nasution, 2008:231). Namun, hasilnya belum cukup efektif mengingat kompleksitas masalah KDRT belum menyentuh pada proses penyadaran keluarga untuk meningkatkan kualitas diri melalui penerapan 8 fungsi keluarga. Di negara-negara seperti Inggris ataupun Amerika, peran perlindungan anak maupun perempuan sangat mengandalkan negara/pemerintah. Di sisi lain, terdapat pergeseran pendekatan proteksi anak yang mengarah peningkatan partisipasi keluarga dalam perencanaan proteksi dalam konteks pekerjaan sosial (Munro, 2011: 105).

Dalam kerangka perlindungan dan pengembangan sumberdaya manusia (SDM) yang handal fungsi kasih sayang/perlindungan, tidak dapat dipisahkan dari delapan fungsi keluarga. Ketujuh fungsi lainnya seperti fungsi agama, fungsi reproduksi dan kesehatan, fungsi pendidikan, fungsi ekonomi dan fungsi lingkungan (Suyono dan Haryanto,
2007:5). Diasumsikan bahwa seandainya masing-masing keluarga dapat menjalankan peran dan fungsinya secara maksimal dalam melindungi dan mendidik anak-anaknya; maka akan terbentuk masyarakat yang teratur (in-order society), berbudaya dan bermartabat (civilized society) serta sejahtera (prosperous society).

\section{Kekerasan dalam Rumah Tangga}

Kekerasan keluarga family violence atau kekerasan rumahtangga (domestic violence), menurut Pasal 1 UU Nomor 23 tahun 2004 tentang Penghapusan Kekerasan dalam Rumah Tangga (UU PKDRT) adalah setiap perbuatan terhadap seseorang terutama perempuan, yang berakibat timbulnya kesengsaraan atau penderitaan secara fisik, seksual, psikologis, dan/atau penelantaran rumah tangga termasuk ancaman untuk melakukan perbuatan, pemaksaan, atau perampasan kemerdekaan secara melawan hukum dalam lingkup rumah tangga. Seseorang yang dimaksud dalam pasal tersebut dijelaskan dalam Pasal 2 meliputi suami, istri, anak, orang-orang yang mempunyai hubungan keluarga dan pembantu rumah tangga yang tinggal serumah.

Beberapa hasil kajian tentang KDRT beserta lingkup kajian, temuan, dan faktor-faktor

\section{Tabel 1
Daftar Penelitian tentang KDRT dan Lingkup Kajiannya}

\begin{tabular}{|c|c|c|}
\hline No & $\begin{array}{l}\text { Peneliti dan Tahun } \\
\text { Pelaksanaan }\end{array}$ & Temuan yang Diperoleh \\
\hline 1 & Mutiarawana (2010) & $\begin{array}{l}\text { - Faktor-faktor yang berhubungan dengan KDRT antara lain, rendahnya } \\
\text { pendapatan suami dan masih dianutnya budaya patriarkhi dalam rumah } \\
\text { tangga. } \\
\text { - Penelitian di Bogor menemukan adanya jenis-jenis kekerasan terhadap } \\
\text { istri yang meliputi kekerasan fisik, psikis, seksual, sosial dan ekonomi. } \\
\text { - Istri lebih banyak mengalami kekerasan fisik dan psikis dan kekerasan } \\
\text { sosial. }\end{array}$ \\
\hline 2 & Ayesha (2012) & $\begin{array}{l}\text { - Penelitian di Subang menunjukkan bahwa pelaku KDRT adalah suami } \\
\text { dengan karakteristik sebagai berikut: usia dalam kategori dewasa awal, } \\
\text { lulus SMA, bekerja sebagai karyawan swasta, pendapatan rendah (di } \\
\text { bawah UMR). } \\
\text { - Kekerasan yang banyak dialami oleh istri adalah kekerasan fisik dan } \\
\text { ekonomi. }\end{array}$ \\
\hline 3 & Fauziani (2012) & $\begin{array}{l}\text { - Pelaku KDRT tidak hanya suami, namun juga ibu mertua yang tinggal } \\
\text { satu rumah begitu juga sebaliknya istri melakukan kekerasan terhadap } \\
\text { ibu mertua. } \\
\text { - Dampak KDRT yang dirasakan istri lebih banyak memberikan dampak } \\
\text { psikologis daripada fisik, dalam hal ini banyak istri yang mengalami } \\
\text { stress ringan. }\end{array}$ \\
\hline 4 & $\begin{array}{l}\text { Putri dan Santoso } \\
(2012)\end{array}$ & $\begin{array}{l}\text { - Ditemukan pula KDRT berupa kekerasan verbal yang dilakukan oleh } \\
\text { ibu terhadap anak, seperti membentak dan mencaci. }\end{array}$ \\
\hline
\end{tabular}

Ket.: Hasil kompilasi 
yang berhubungan atau yang memengaruhinya dapat dicermati pada Tabel 1.

Adapun bentuk-bentuk kekerasan dalam keluarga meliputi kekerasan fisik, seksual, psikologis, budaya, sosial, ekonomi dan politik (Sutinah dan Kinasih 2008: 23; Mutiarawana, 2010: 63; Ayesha, 2012: 59; Fauzani, 2012: 72). Selain bentuk-bentuk tersebut, terdapat kekerasan verbal yang dilakukan oleh ibu terhadap anak seperti membentak (Putri dan Santoso, 2012: 22; Fauzani, 2012: 73) dan dapat menimbulkan kekerasan psikis seperti dimarahi, dicaci, tidak dipercaya dan tidak dihargai, sedangkan bentuk kekerasan fisik seperti ditampar, dipukul, dicekek, dipotong rambutnya dan didorong hingga jatuh serta ditendang (Sutinah dan Kinasih, 2008: 26; Fachrina dan Anggraini, 2007: 5).

Faktor-faktor yang memengaruhi kekerasan dalam keluarga terhadap perempuan (istri) bersifat khas terkait dengan budaya patriarkhi, berbeda halnya dengan faktor yang memengaruhi kekerasan terhadap anak. Faktor lain pengaruh bapak sebagai role model, anak laki-laki yang tumbuh dalam lingkungan dimana ayah sering memukul ibunya, akan cenderung meniru pola tersebut kepada pasangannya kelak (Muniarti dalam Fachrina dan Anggraini 2007: 5). Adapun faktor yang memengaruhi kekerasan pada anak, yaitu karakteristik demografi seperti depresi ibu, penggunaan alkohol oleh ibu, dan pola kekerasan dalam keluarga (Cardoso dan Fong 2010: 315).

Pelaku kekerasan melibatkan anggota keluarga, teman (orang yang dikenal) (Nursanti 2010:130), orang asing, baik secara langsung ataupun tidak langsung (GrahamBermann \& Levendosky, 1998; O'Donnell, Schwab-Stone \& Ruchkin, 2006 dalam Chan dan Yeung, 2009: 316). Pelaku kekerasan dari hasil penelitian Nursanti (2010:130) yaitu tetangga, orangtua, saudara, guru dan majikan. Akibat kekerasan yang lebih parah (merusak, membahayakan, dan memberikan dampak lama) apabila pelaku adalah anggota keluarga terdekat (DuRant, Getts, Cadenhead, Emans \& Woods, 1995; Osofsky, Wewers, Hann \& Fick, 1993 dalam Chan dan Yeung, 2009: 317).

\section{Dampak Kekerasan dalam Rumah Tangga}

Efek kekerasan terhadap korban memengaruhi kehidupan dan perkembangan selanjutnya serta menimbulkan gangguan mental pada anak-anak dan orang dewasa serta gejala stres (Dahlberg \& Krug, 2002; Emery, 2001 seperti dikutip Chan dan Yeung, 2009: 317; Ayesha, 2012: 59). Selain itu, dapat mengakibatkan masalah adaptasi (adjustment problems) termasuk gangguan psikologis, gangguan perilaku, takut perpisahan, takut kematian, kesepian dan terasing, galau, tidak menikmati aktivitas keseharian, tidak peduli, mengalami gangguan tidur dan mimpi buruk (Kerig, 1999; Skopp, McDonald, Manke \& Jouriles, 2006; SturgeApple, Davies \& Cummings, 2006 seperti dikutip oleh Chan dan Yeung 2009: 317).

Kekerasan dalam rumah tangga telah menjadi perhatian utama para profesional kesehatan hari ini. Dalam rangka memberikan intervensi secara efektif, penelitian ilmiah perlu dilakukan untuk mengatasi parameter teoretis kekerasan dalam rumah tangga. $\mathrm{Hal}$ ini penting untuk analisis sosial-politik sementara juga menunjukkan bahwa konsep saling ketergantungan keluarga dapat membantu, tidak hanya dalam memahami kekerasan dalam keluarga, tetapi juga dalam memberikan arahan untuk intervensi di tingkat keluarga (Fishel dan Rynerson, 1998: 295). Kekerasan dalam rumah tangga juga memiliki efek yang signifikan pada kesehatan umum dan reproduksi perempuan, dan dapat menyebabkan komplikasi serius dan dapat berakhir dengan kematian. Penelitian menunjukkan bahwa perempuan mengalami kekerasan memiliki kondisi kesehatan yang buruk dan manfaat kurang dari pelayanan kesehatan daripada yang lain.

Oleh karena itu, tenaga kesehatan memiliki tanggung jawab penting untuk mendefinisikan kekerasan dalam rumah tangga dan campur tangan bila diperlukan. Personil ini juga harus dididik dalam hal kekerasan dalam rumah tangga, kebijakan dan protokol yang efektif harus diletakkan pada tempatnya. Hal yang sangat penting, tenaga kesehatan harus didukung oleh manajer mereka ketika mereka mencoba untuk menangani masalah-masalah yang berkaitan dengan kekerasan dalam rumah tangga (Akuz et al., 2012: 514).

Dampak kekerasan pada anak berhubungan dengan tipe adaptasi anakanak terhadap masalah yang dialaminya. Terdapat hubungan antara pelapor atau sumber informasi kekerasan dengan efek kekerasan, karena hubungan kedekatan (emosional) dengan korban. Terdapat hubungan jumlah sumber dengan seberapa besar efek kekerasan, karena banyak pelapor 
lebih objektif dibandingkan dengan satu pelapor (Chan dan Yeung, 2009: 318).

Secara garis besar baik kekerasan yang dilakukan di tingkat keluarga disebabkan karena tekanan ekonomi. Salah satu cara yang diharapkan dapat menyelesaikan masalah ini adalah melalui pemberdayaan keluarga (Puspitawati, 2009: 112). Dari penelitian yang dilakukan Puspitawati, Herawati, Hastuti, dan Trikoesoemaningtyas (2008:97) menunjukkan bahwa program pemberdayaan keluarga dapat meningkatkan pendapatan keluarga meskipun masih dalam skala kecil.

Timbulnya sifat kekerasan dalam rumah tangga, antara lain, dapat pula dipengaruhi oleh faktor media massa. Hal ini sejalan dengan hasil penelitian Pawito dan Kartono (2013: 111) yang menyatakan bahwa,

identitas kultural sebenarnya dikonstruksi secara sosial oleh masyarakat dengan pengaruh media massa global. Demikian pula temuan Astuti (2013: 41) bahwa kajian seputar dampak kekerasan di media terhadap penonton menunjukkan adanya pengaruh langsung maupun tidak langsung antara tayangan kekerasan dengan penonton.

Tujuan tulisan ini adalah menganalisis perbandingan KDRT yang dilakukan oleh suami terhadap istri dan istri terhadap suami yang terjadi di Kabupaten Cianjur dan Indramayu; baik berupa kekerasan fisik, sosial, psikis, ekonomi, maupun seksual. Menganalisis perbandingan KDRT yang dilakukan oleh suami terhadap istri dan istri terhadap suami yang terjadi di Kabupaten Cianjur dan Indramayu menurut jenis kelamin. Memberikan rekomendasi bagaimana mengatasi KDRT yang terjadi di masyarakat.

Penelitian ini dilakukan di dua lokasi terpilih, yaitu Kabupaten Indramayu dan Kabupaten Cianjur yang ditentukan atas pertimbangan bahwa kedua lokasi tersebut mewakili ragam perdesaan ekologis berbeda dan memunyai tingkat kekerasan rumah tangga yang cukup tinggi berdasarkan data sekunder. Sampel dipilih dari 2 kecamatan dan 4 desa dengan jumlah responden 178 keluarga, dimana kriteria keluarga yang dipilih adalah keluarga yang memiliki suami dan istri. Sampel yang berasal dari Kabupaten Cianjur sebanyak 88 keluarga dan yang berasal dari Kabupaten Indramayu sebanyak 90 keluarga. Selain itu, dipilih sepuluh orang tokoh masyarakat pada setiap kabupaten sebagai informan, sehingga total informan sebanyak 20 orang. Data terkait kekerasan dalam rumah tangga yang terhimpun di lokasi penelitian, selanjutnya dianalisis dan dibandingkan dengan uji T-test.

\section{KDRT Suami terhadap Istri}

Uji beda T-test dilakukan untuk mengetahui perbedaan antara Kabupaten Cianjur dan Indramayu dalam intensitas kekerasan yang dilakukan suami terhadap istri dan sebaliknya. Pada variabel kekerasan

Tabel 2

Perbandingan Kekerasan Fisik Suami terhadap Istri menurut Kabupaten

\begin{tabular}{|c|c|c|c|c|}
\hline \multirow[b]{2}{*}{ No } & \multirow[b]{2}{*}{ Kekerasan Fisik } & \multicolumn{2}{|c|}{ Rataan } & \multirow[b]{2}{*}{ T-test } \\
\hline & & $\begin{array}{l}\text { Cianjur } \\
(\mathrm{N}=\mathbf{8 8})\end{array}$ & $\begin{array}{l}\text { Indramayu } \\
(\mathrm{N}=90)\end{array}$ & \\
\hline 1. & Memukul tanpa menggunakan benda tertentu & 1.01 & 1.01 & 0.987 \\
\hline 2. & $\begin{array}{l}\text { Memukul dengan menggunakan benda tertentu } \\
\text { seperti bambu, ikat pinggang, rotan, dan lain-lain }\end{array}$ & 1.00 & 1.00 & \\
\hline 3. & Mencubit & 1.01 & 1.02 & 0.666 \\
\hline 4. & Mencakar & 1.00 & 1.00 & \\
\hline 5. & Menampar & 1.00 & 1.01 & 0.324 \\
\hline 6. & Menyiram air (keterangan panas/dingin) & 1.00 & 1.01 & 0.324 \\
\hline 7. & $\begin{array}{l}\text { Menganiaya dengan menggunakan benda tertentu } \\
\text { seperti rokok, setrika, bensin, dan lain-lain }\end{array}$ & 1.00 & 1.00 & \\
\hline 8. & Melempar barang & 1.00 & 1.01 & 0.324 \\
\hline 9. & Menarik/menjambak rambut & 1.00 & 1.00 & \\
\hline 10. & Menusukkan benda tajam pada bagian badan & 1.00 & 1.00 & \\
\hline 11. & Mendorong hingga terjatuh & 1.00 & 1.00 & \\
\hline 12. & Menendang & 1.01 & 1.00 & 0.313 \\
\hline & Total & 12.03 & 12.07 & 0.504 \\
\hline
\end{tabular}


Tabel 3

Perbandingan Kekerasan Sosial Suami terhadap Istri menurut Kabupaten

\begin{tabular}{llccc}
\hline \multirow{2}{*}{ No } & \multicolumn{1}{c}{ Kekerasan Sosial } & \multicolumn{2}{c}{ Rataan } & T-test \\
\cline { 3 - 4 } & & $\begin{array}{c}\text { Cianjur } \\
\mathbf{( N = 8 8 )}\end{array}$ & $\begin{array}{c}\text { Indramayu } \\
\mathbf{( N = 9 0 )}\end{array}$ & 0.772 \\
\hline 1. & Mengucilkan atau mengabaikan & 1.14 & 1.16 & $0.017 *$ \\
\hline 2. & Mengasingkan istri dari keluarga besar & 1.01 & 1.12 & 0.170 \\
\hline $\begin{array}{l}\text { Memaksa untuk melakukan sesuatu demi } \\
\text { kepentingan ekonomi, misalnya mengemis, } \\
\text { mencuri, melacur, dan lain-lain }\end{array}$ & 1.00 & 1.06 & 0.056 \\
\hline
\end{tabular}

Ket.: $1=$ Tidak pernah, 2=Kurang dari 2 kali dalam sebulan, 3=3-4 kali dalam sebulan, $4=$ Lebih dari empat kali dalam sebulan * $p \leq 0.05=$ berbeda nyata

fisik yang dilakukan oleh suami terhadap istri, antara Kabupaten Cianjur dan Indramayu tidak ada perbedaan. Kekerasan fisik di kedua wilayah penelitian berada pada rentang tidak pernah hingga dilakukan kurang dari 2 kali dalam sebulan. Secara detail, perbandingan kekerasan fisik suami terhadap istri menurut kabupaten dapat dilihat pada Tabel 2.

Variabel kekerasan sosial yang dilakukan oleh suami terhadap istri diukur dengan pernyataan mengucilkan atau mengabaikan, mengasingkan suami/ istri dari keluarga besar dan memaksa untuk melakukan sesuatu demi kepentingan ekonomi, misalnya mengemis, mencuri, melacur, dan lain-lain. Berdasarkan hasil analisis diketahui bahwa terdapat perbedaan nyata $(p=0.017)$ antara Kabupaten Cianjur (rata-rata=1.01) dan Indramayu (rata-rata $=1.12$ ) pada pernyataan suami mengasingkan istri dari keluarga besar.

Hasil temuan tersebut menunjukkan bahwa dalam hal mengasingkan istri dari keluarga besar, suami di Kabupaten Indramayu lebih dominan dibanding suami di Kabupaten Cianjur. Keterangan secara detail perbandingan kekerasan sosial suami terhadap istri menurut kabupaten disajikan pada Tabel 3.

Secara umum, kekerasan psikis yang dilakukan oleh suami terhadap istri di kedua kabupaten tidak berbeda nyata. Namun, terdapat perbedaan nyata dan signifikan pada pernyataan suami menggoda wanita lain ketika berpergian dengan pasangan $(p=0.004)$, dengan rata-rata untuk Kabupaten Cianjur adalah 1.00 dan Kabupaten Indramayu 1.20.

Hasil temuan tersebut menunjukkan bahwa dalam hal menggoda wanita lain ketika berpergian dengan pasangan, suami di Kabupaten Indramayu lebih dominan dibanding suami di Kabupaten Cianjur. Secara detail, uraian lengkap perbandingan kekerasan psikis suami terhadap istri menurut kabupaten disajikan pada Tabel 4.

Kekerasan dalam rumah tangga yang dilakukan oleh suami terhadap istri dalam bentuk kekerasan ekonomi di kedua kabupaten lokasi penelitian tidak berbeda nyata. Rata-rata responden menjawab tidak pernah hingga dilakukan kurang dari 2 kali dalam sebulan pada pernyataan-pernyataan yang mengukur potensi kekerasan ekonomi. Secara detail, hasil analisis perbandingan kekerasan ekonomi suami terhadap istri menurut kabupaten disajikan pada Tabel 5.

Berdasarkan hasil analisis, terdapat perbedaan nyata dan signifikan $(p=0.013)$ kekerasan seksual yang dilakukan oleh suami terhadap istri di dua kabupaten lokasi penelitian, dengan rata-rata di Kabupaten Cianjur 6.01 dan Kabupaten Indramayu 6.18. Tabel 5 menunjukkan terdapat perbedaan nyata dan signifikan $(p=0.035)$ pada pernyataan suami memaksa untuk berhubungan intim ketika istri sedang lelah atau sakit, dengan rata-rata di Kabupaten Cianjur adalah 1.00 dan Kabupaten Indramayu 1.08.

Temuan tersebut menunjukkan bahwa dalam hal memaksa untuk berhubungan intim ketika istri sedang lelah atau sakit, suami di Kabupaten Indramayu lebih dominan dibanding suami di Kabupaten Cianjur. Demikian pula secara total, terdapat perbedaan yang nyata bahwa kekerasan seksual oleh suami di Kabupaten Indramayu lebih dominan dibanding suami di Kabupaten Cianjur. Secara detail, hasil analisis perbandingan kekerasan seksual suami terhadap istri 
Tabel 4

Perbandingan Kekerasan Psikis Suami terhadap Istri menurut Kabupaten

\begin{tabular}{|c|c|c|c|c|}
\hline \multirow[b]{2}{*}{ No } & \multirow[b]{2}{*}{ Kekerasan Psikis } & \multicolumn{2}{|c|}{ Rataan } & \multirow[b]{2}{*}{ T-test } \\
\hline & & $\begin{array}{l}\text { Cianjur } \\
(\mathrm{N}=\mathbf{8 8})\end{array}$ & $\begin{array}{c}\text { Indramayu } \\
(\mathrm{N}=90)\end{array}$ & \\
\hline 1. & Mengusir/menyuruh minggat & 1.00 & 1.02 & 0.161 \\
\hline 2. & $\begin{array}{l}\text { Mengatakan bahwa bukanlah seseorang yang } \\
\text { diinginkan untuk menjadi pendamping }\end{array}$ & 1.00 & 1.02 & 0.161 \\
\hline 3. & $\begin{array}{l}\text { Menghina dengan menggunakan sebutan yang } \\
\text { tidak menyenangkan seperti bodoh, tolol, jelek, } \\
\text { dan lain-lain }\end{array}$ & 1.06 & 1.16 & 0.139 \\
\hline 4. & $\begin{array}{l}\text { Menyalahkan atas segala masalah yang ada dalam } \\
\text { keluarga }\end{array}$ & 1.25 & 1.30 & 0.620 \\
\hline 5. & $\begin{array}{l}\text { Menghina sebagai isteri yang tidak becus mengurus } \\
\text { rumah tangga dan anak }\end{array}$ & 1.07 & 1.19 & 0.082 \\
\hline 6. & Mengkritik dengan pedas tanpa perasaan & 1.14 & 1.10 & 0.547 \\
\hline 7. & Mengancam akan disiksa/dibunuh & 1.00 & 1.12 & 0.027 \\
\hline 8. & Mengurung atau menyekap dalam ruangan & 1.00 & 1.00 & \\
\hline 9. & Menghina sebagai isteri yang tidak berguna/sialan & 1.01 & 1.00 & 0.313 \\
\hline 10. & Menghina sebagai manusia rendah/miskin & 1.02 & 1.00 & 0.152 \\
\hline 11. & Mengatai untuk mati saja & 1.07 & 1.07 & 0.977 \\
\hline 12. & Tidak menegur dalam waktu yang cukup lama & 1.62 & 1.47 & 0.177 \\
\hline 13. & Berbicara dengan nada membentak (keras/tinggi) & 1.34 & 1.51 & 0.130 \\
\hline 14. & $\begin{array}{l}\text { Menggoda wanita lain ketika berpergian dengan } \\
\text { pasangan }\end{array}$ & 1.00 & 1.20 & $0.004 *$ \\
\hline 15. & Tidak peduli ketika dalam kondisi sakit & 1.00 & 1.03 & 0.184 \\
\hline & Total & 16.58 & 17.19 & 0.109 \\
\hline
\end{tabular}

Ket.: $1=$ Tidak pernah, $2=$ Kurang dari 2 kali dalam sebulan, $3=3-4$ kali dalam sebulan, $4=$ Lebih dari empat kali dalam sebulan $* p \leq 0.05=$ berbeda nyata

Tabel 5

Perbandingan Kekerasan Ekonomi Suami terhadap Istri menurut Kabupaten

\begin{tabular}{|c|c|c|c|c|}
\hline \multirow[b]{2}{*}{ No } & \multirow[b]{2}{*}{ Kekerasan Ekonomi } & \multicolumn{2}{|c|}{ Rataan } & \multirow[b]{2}{*}{ T-test } \\
\hline & & $\begin{array}{l}\text { Cianjur } \\
(\mathrm{N}=\mathbf{8 8})\end{array}$ & $\begin{array}{l}\text { Indramayu } \\
(\mathrm{N}=90)\end{array}$ & \\
\hline 1. & $\begin{array}{l}\text { Tidak mendapatkan uang belanja makan keluarga } \\
\text { padahal pasangan memiliki uang }\end{array}$ & 1.05 & 1.07 & 0.633 \\
\hline 2. & $\begin{array}{l}\text { Tidak mendapatkan uang belanja pakaian padahal } \\
\text { pasangan memiliki uang }\end{array}$ & 1.05 & 1.07 & 0.609 \\
\hline 3. & $\begin{array}{l}\text { Tidak mendapatkan uang belanja pendidikan anak } \\
\text { padahal pasangan memiliki uang }\end{array}$ & 1.05 & 1.03 & 0.744 \\
\hline 4. & $\begin{array}{l}\text { Membebani utang tanpa sepengetahuan pasangan } \\
\text { terlebih dulu }\end{array}$ & 1.05 & 1.06 & 0.801 \\
\hline 5. & $\begin{array}{l}\text { Tidak mendapatkan perwatan kesehatan padahal } \\
\text { pasangan memiliki uang }\end{array}$ & 1.02 & 1.03 & 0.753 \\
\hline 6. & $\begin{array}{l}\text { Tidak diizinkan bekerja walaupun mempunyai } \\
\text { keinginan bekerja karena pasangan bisa menanggung }\end{array}$ & 1.17 & 1.18 & 0.922 \\
\hline 7. & $\begin{array}{l}\text { Mendorong anak usia wajib belajar ( }<15 \text { tahun) } \\
\text { untuk bekerja }\end{array}$ & 1.09 & 1.10 & 0.882 \\
\hline & Total & 7.47 & 7.53 & 0.772 \\
\hline
\end{tabular}

Ket.: $1=$ Tidak pernah, 2=Kurang dari 2 kali dalam sebulan, 3=3-4 kali dalam sebulan, $4=$ Lebih dari empat kali dalam sebulan 
Tabel 6

Perbandingan Kekerasan Seksual Suami terhadap Istri menurut Kabupaten

\begin{tabular}{|c|c|c|c|c|}
\hline \multirow[b]{2}{*}{ No } & \multirow[b]{2}{*}{ Kekerasan Seksual } & \multicolumn{2}{|c|}{ Rataan } & \multirow[b]{2}{*}{ T-test } \\
\hline & & $\begin{array}{l}\text { Cianjur } \\
(N=88)\end{array}$ & $\begin{array}{c}\text { Indramayu } \\
(N=90)\end{array}$ & \\
\hline 1. & $\begin{array}{l}\text { Meraba-raba/menyentuh bagian sensitif secara paksa } \\
\text { hingga terluka }\end{array}$ & 1.00 & 1.04 & 0.105 \\
\hline 2. & $\begin{array}{l}\text { Memaksa untuk melakukan hubungan suami isteri } \\
\text { ketika sedang datang bulan }\end{array}$ & 1.01 & 1.01 & \\
\hline 3. & $\begin{array}{l}\text { Melakukan kekerasan pada saat berhubungan intim } \\
\text { hingga merasa kesakitan }\end{array}$ & 1.00 & 1.03 & 0.987 \\
\hline 4. & $\begin{array}{l}\text { Memaksa untuk menjadi orang lain pada saat } \\
\text { berhubungan intim (dipaksa untuk tidak menjadi } \\
\text { diri sendiri) }\end{array}$ & 1.00 & 1.00 & 0.184 \\
\hline 5. & $\begin{array}{l}\text { Memaksa untuk berhubungan intim ketika Anda } \\
\text { sedang lelah atau sakit }\end{array}$ & 1.00 & 1.08 & $0.035 *$ \\
\hline 6. & Mengalami perlakuan seks tidak wajar & 1.00 & 1.01 & 0.324 \\
\hline & Skor Total & 6.01 & 6.18 & $0.013 *$ \\
\hline
\end{tabular}

Tabel 7

Perbandingan Kekerasan Fisik Istri terhadap Suami menurut Kabupaten

\begin{tabular}{|c|c|c|c|c|}
\hline \multirow[b]{2}{*}{ No } & \multirow[b]{2}{*}{ Kekerasan Fisik } & \multicolumn{2}{|c|}{ Rataan } & \multirow[b]{2}{*}{ T-test } \\
\hline & & $\begin{array}{l}\text { Cianjur } \\
(\mathrm{N}=\mathbf{8 8})\end{array}$ & $\begin{array}{c}\text { Indramayu } \\
(\mathrm{N}=90)\end{array}$ & \\
\hline 1. & Memukul tanpa menggunakan benda tertentu & 1.00 & 1.02 & 0.161 \\
\hline 2. & $\begin{array}{l}\text { Memukul dengan menggunakan benda tertentu seperti } \\
\text { bambu, ikat pinggang, rotan, dan lain-lain }\end{array}$ & 1.00 & 1.00 & \\
\hline 3. & Mencubit & 1.01 & 1.02 & 0.666 \\
\hline 4. & Mencakar & 1.00 & 1.00 & \\
\hline 5. & Menampar & 1.00 & 1.03 & 0.085 \\
\hline 6. & Menyiram air (keterangan panas/dingin) & 1.00 & 1.00 & \\
\hline 7. & $\begin{array}{l}\text { Menganiaya dengan menggunakan benda tertentu } \\
\text { seperti rokok, setrika, bensin, dan lain-lain }\end{array}$ & 1.00 & 1.00 & \\
\hline 8. & Melempar barang & 1.00 & 1.00 & \\
\hline 9. & Menarik/menjambak rambut & 1.00 & 1.00 & \\
\hline 10. & Menusukkan benda tajam pada bagian badan & 1.00 & 1.00 & \\
\hline 11. & Mendorong hingga terjatuh & 1.00 & 1.00 & \\
\hline 12. & Menendang & 1.01 & 1.00 & 0.313 \\
\hline & Skor Total & 12.02 & 12.08 & 0.201 \\
\hline
\end{tabular}

Tabel 8

Perbandingan Kekerasan Sosial Istri terhadap Suami menurut Kabupaten

\begin{tabular}{|c|c|c|c|c|}
\hline \multirow[b]{2}{*}{ No } & \multirow[b]{2}{*}{ Kekerasan Sosial } & \multicolumn{2}{|c|}{ Rataan } & \multirow[b]{2}{*}{ T-test } \\
\hline & & $\begin{array}{l}\text { Cianjur } \\
(\mathbf{N}=\mathbf{8 8})\end{array}$ & $\begin{array}{c}\text { Indramayu } \\
(\mathrm{N}=90)\end{array}$ & \\
\hline 1. & Mengucilkan atau mengabaikan & 1.14 & 1.07 & 0.190 \\
\hline 2. & Mengasingkan Anda dari keluarga besar & 1.00 & 1.03 & 0.085 \\
\hline 3. & $\begin{array}{l}\text { Memaksa untuk melakukan sesuatu demi } \\
\text { kepentingan ekonomi, misalnya mengemis, } \\
\text { mencuri, melacur, dan lain-lain }\end{array}$ & 1.02 & 1.03 & 0.720 \\
\hline & Total & 3.16 & 3.13 & 0.705 \\
\hline
\end{tabular}


menurut kabupaten disajikan pada Tabel 6 .

\section{KDRT Istri terhadap Suami}

Potensi kekerasan dalam rumah tangga yang ditanyakan kepada istri juga ditanyakan kepada suami. Kekerasan fisik yang dilakukan oleh istri terhadap suami pada kedua kabupaten tidak berbeda nyata. Jawaban responden suami pada pernyataan kekerasan fisik di kedua kabupaten rata-rata tidak pernah hingga kurang dari 2 kali dalam sebulan. Hasil analisis disajikan secara detail pada Tabel 7.

Hasil analisis uji beda T-test untuk mengetahui kekerasan sosial yang dilakukan istri terhadap suami menunjukkan bahwa tidak terdapat perbedaan antara Kabupaten Cianjur dan Kabupaten Indramayu. Tabel 8 menunjukkan hasil analisis secara detail.

Secara keseluruhan, tidak terdapat perbedaan pada kekerasan psikis antara Kabupaten Cianjur dan Kabupaten Indramayu. Namun, terdapat perbedaan nyata dan signifikan pada pernyataan istri menggoda pria lain ketika berpergian dengan pasangan $(p=0.010)$ dengan rata-rata di Kabupaten Cianjur 1.00 dan rata-rata Kabupaten Indramayu 1.16. Hasil temuan tersebut menunjukkan bahwa dalam hal menggoda pria lain, istri di Kabupaten Indramayu lebih berani dibanding istri di Kabupaten Cianjur. Hasil analisis secara detail disajikan pada Tabel 9.

Tabel 10 menunjukkan hasil analisis uji beda kekerasan ekonomi yang dilakukan istri terhadap suami di kedua kabupaten lokasi penelitian. Hasil analisis menunjukkan bahwa kekerasan ekonomi yang dilakukan oleh istri terhadap suami pada kedua lokasi tidak berbeda nyata.

Bentuk kekerasan dalam rumah tangga yaitu kekerasan seksual yang dilakukan istri kepada suami secara keseluruhan tidak berbeda nyata. Namun, terdapat perbedaan nyata dan signifikan $(p=0.035)$ pada pernyataan istri memaksa untuk berhubungan intim ketika suami sedang lelah atau sakit, dengan rata-rata di Kabupaten Cianjur adalah 1.00 dan rata-rata di Kabupaten Indramayu 1.08. Hasil temuan tersebut menunjukkan bahwa dalam hal memaksa untuk berhubungan intim ketika suami sedang lelah atau sakit, istri di Kabupaten Indramayu lebih dominan dibanding istri di Kabupaten Cianjur. Hasil analisis secara detail disajikan pada Tabel 11.
Pada Tabel 12 menunjukkan perbedaan kekerasan rumah tangga yang terjadi di kedua lokasi penelitian. Hasil analisis menunjukkan kekerasan dalam rumah tangga yang dilakukan suami terhadap istri di kedua kabupaten tidak berbeda nyata, dengan rata-rata Kabupaten Cianjur 45.24 dan Kabupaten Indramayu 46.30. Sementara itu, kekerasan rumah tangga yang dilakukan oleh istri terhadap suami terdapat perbedaan nyata $(p=0.039)$ antara Kabupaten Cianjur (rata-rata $=45.18$ ) dan Kabupaten Indramayu (rata-rata=45.38). Hasil temuan tersebut menunjukkan bahwa intensitas kekerasan rumah tangga yang dilakukan istri terhadap suami di Kabupaten Indramayu lebih tinggi dibanding istri di Kabupaten Cianjur. Hal ini diduga terjadi karena faktor budaya, norma dan nilai-nilai yang berbeda antara masyarakat Indramayu dan Cianjur, serta faktor-faktor penyebab lainnya.

Secara umum, hasil uji beda potensi kekerasan dalam rumahtangga yang dilakukan oleh suami terhadap istri maupun istri terhadap suami berdasarkan jenis kelamin sampel disajikan pada Tabel 13. Hasil analisis menunjukkan bahwa tidak terdapat perbedaan nyata antara sampel laki-laki dan perempuan pada kekerasan dalam rumah tangga yang dilakukan suami terhadap istri. Kesimpulan yang sama juga pada kekerasan dalam rumah tangga yang dilakukan istri terhadap suami, yaitu tidak terdapat perbedaan nyata jika dibandingkan antara pihak laki-laki dan perempuan.

Pada umumnya KDRT yang dialami oleh individu, baik di Kabupaten Cianjur maupun Kabupaten Indramayu, penyebabnya tidak terlepas dari kondisi sosial ekonomi, budaya, norma, agama dan nilai-nilai yang ada di masyarakat tersebut. Selain itu, penyebab KDRT dapat pula berasal dari dalam individu korban itu sendiri (faktor internal) atau dari masyarakat sekitar di mana individu itu berinteraksi (faktor eksternal). Adanya faktor internal dan eksternal sebagai penyebab munculnya kasus KDRT memudahkan untuk mengidentifikasi karakteristik anggota keluarga dan keluarganya yang mengalami tindakan kekerasan tersebut.

Mengacu pada hasil penelitian Mutiarawana (2010: 63) bahwa faktor-faktor yang berhubungan dengan KDRT, antara lain rendahnya pendapatan suami dan masih dianutnya budaya patriarkhi dalam rumah tangga. Penelitian tersebut juga menemukan adanya jenis-jenis kekerasan terhadap istri 
Tabel 9

Perbandingan kekerasan Psikis Istri terhadap Suami menurut Kabupaten

\begin{tabular}{|c|c|c|c|c|}
\hline \multirow[b]{2}{*}{ No } & \multirow[b]{2}{*}{ Kekerasan Psikis } & \multicolumn{2}{|c|}{ Rataan } & \multirow[b]{2}{*}{ T-test } \\
\hline & & $\begin{array}{l}\text { Cianjur } \\
(\mathbf{N}=\mathbf{8 8})\end{array}$ & $\begin{array}{l}\text { Indramayu } \\
(\mathrm{N}=90)\end{array}$ & \\
\hline 1. & Mengusir/menyuruh minggat & 1.06 & 1.02 & 0.425 \\
\hline 2. & $\begin{array}{l}\text { Mengatakan bahwa bukanlah seseorang yang } \\
\text { diinginkan untuk menjadi pendamping }\end{array}$ & 1.01 & 1.02 & 0.576 \\
\hline 3. & $\begin{array}{l}\text { Menghina dengan menggunakan sebutan yang } \\
\text { tidak menyenangkan seperti bodoh, tolol, jelek, } \\
\text { dan lain-lain }\end{array}$ & 1.10 & 1.13 & 0.674 \\
\hline 4. & $\begin{array}{l}\text { Menyalahkan atas segala masalah yang ada dalam } \\
\text { keluarga }\end{array}$ & 1.16 & 1.26 & 0.259 \\
\hline 5. & $\begin{array}{l}\text { Menghina sebagai suami yang tidak becus mengurus } \\
\text { rumah tangga dan anak }\end{array}$ & 1.07 & 1.13 & 0.294 \\
\hline 6. & Mengkritik dengan pedas tanpa perasaan & 1.09 & 1.11 & 0.691 \\
\hline 7. & Mengancam akan disiksa/dibunuh & 1.00 & 1.08 & 0.111 \\
\hline 8. & Mengurung atau menyekap dalam ruangan & 1.00 & 1.08 & 0.324 \\
\hline 9. & Menghina sebagai suami yang tidak berguna/sialan & 1.00 & 1.01 & 0.313 \\
\hline 10. & Menghina sebagai manusia rendah/miskin & 1.01 & 1.00 & 0.313 \\
\hline 11. & Mengatai untuk mati saja & 1.03 & 1.06 & 0.578 \\
\hline 12. & Tidak menegur dalam waktu yang cukup lama & 1.62 & 1.41 & 0.061 \\
\hline 13. & Berbicara dengan nada membentak (keras/tinggi) & 1.40 & 1.44 & 0.685 \\
\hline 14. & $\begin{array}{l}\text { Menggoda pria lain ketika berpergian dengan } \\
\text { pasangan }\end{array}$ & 1.00 & 1.16 & $0.010 *$ \\
\hline 15. & Tidak peduli ketika dalam kondisi sakit & 1.00 & 1.03 & 0.184 \\
\hline & Skor Total & 16.57 & 16.87 & 0.417 \\
\hline
\end{tabular}

Ket.: Ket.: Ket.: 1=Tidak pernah, 2=Kurang dari 2 kali dalam sebulan, 3=3-4 kali dalam sebulan, $4=$ Lebih dari empat kali dalam sebulan * $p \leq 0.05=$ berbeda nyata

Tabel 10

Perbandingan Kekerasan Ekonomi Istri terhadap Suami menurut Kabupaten

\begin{tabular}{|c|c|c|c|c|}
\hline \multirow[b]{2}{*}{ No } & \multirow[b]{2}{*}{ Kekerasan Ekonomi } & \multicolumn{2}{|c|}{ Rataan } & \multirow[b]{2}{*}{ T-test } \\
\hline & & $\begin{array}{l}\text { Cianjur } \\
(\mathrm{N}=\mathbf{8 8})\end{array}$ & $\begin{array}{l}\text { Indramayu } \\
(\mathrm{N}=90)\end{array}$ & \\
\hline 1. & $\begin{array}{l}\text { Tidak mendapatkan uang belanja makan keluarga } \\
\text { padahal pasangan memiliki uang }\end{array}$ & 1.05 & 1.03 & 0.744 \\
\hline 2. & $\begin{array}{l}\text { Tidak mendapatkan uang belanja pakaian padahal } \\
\text { pasangan memiliki uang }\end{array}$ & 1.05 & 1.03 & 0.717 \\
\hline 3. & $\begin{array}{l}\text { Tidak mendapatkan uang belanja pendidikan anak } \\
\text { padahal pasangan memiliki uang }\end{array}$ & 1.02 & 1.01 & 0.644 \\
\hline 4. & $\begin{array}{l}\text { Membebani utang tanpa sepengetahuan pasangan } \\
\text { terlebih dulu }\end{array}$ & 1.10 & 1.01 & 0.066 \\
\hline 5. & $\begin{array}{l}\text { Tidak mendapatkan perwatan kesehatan padahal } \\
\text { pasangan memiliki uang }\end{array}$ & 1.02 & 1.03 & 0.753 \\
\hline 6. & $\begin{array}{l}\text { Tidak diizinkan bekerja walaupun mempunyai } \\
\text { keinginan bekerja karena pasangan bisa menanggung }\end{array}$ & 1.05 & 1.02 & 0.462 \\
\hline 7. & $\begin{array}{l}\text { Mendorong anak usia wajib belajar ( }<15 \text { tahun) } \\
\text { untuk bekerja }\end{array}$ & 1.08 & 1.04 & 0.468 \\
\hline & Skor Total & 7.36 & 7.19 & 0.367 \\
\hline
\end{tabular}

Ket.: Ket.: Ket.: Ket.: $1=$ Tidak pernah, 2=Kurang dari 2 kali dalam sebulan, 3=3-4 kali dalam sebulan, $4=$ Lebih dari empat kali dalam sebulan $* p \leq 0.05=$ berbeda nyata 
Tabel 11

Perbandingan Kekerasan Seksual Istri terhadap Suami menurut Kabupaten

\begin{tabular}{|c|c|c|c|c|}
\hline \multirow[b]{2}{*}{ No } & \multirow[b]{2}{*}{ Kekerasan Seksual } & \multicolumn{2}{|c|}{ Rataan } & \multirow[b]{2}{*}{ T-test } \\
\hline & & $\begin{array}{l}\text { Cianjur } \\
(\mathbf{N}=\mathbf{8 8})\end{array}$ & $\begin{array}{l}\text { Indramayu } \\
(\mathrm{N}=90)\end{array}$ & \\
\hline 1. & $\begin{array}{l}\text { Meraba-raba/menyentuh bagian sensitif secara } \\
\text { paksa hingga terluka }\end{array}$ & 1.02 & 1.02 & 0.985 \\
\hline 2. & $\begin{array}{l}\text { Memaksa untuk melakukan hubungan suami isteri } \\
\text { ketika sedang datang bulan }\end{array}$ & 1.05 & 1.01 & 0.246 \\
\hline 3. & $\begin{array}{l}\text { Melakukan kekerasan pada saat berhubungan intim } \\
\text { hingga merasa kesakitan }\end{array}$ & 1.00 & 1.00 & \\
\hline 4. & $\begin{array}{l}\text { Memaksa untuk menjadi orang lain pada saat } \\
\text { berhubungan intim (dipaksa untuk tidak menjadi } \\
\text { diri sendiri) }\end{array}$ & 1.00 & 1.00 & \\
\hline 5. & $\begin{array}{l}\text { Memaksa untuk berhubungan intim ketika Anda } \\
\text { sedang lelah atau sakit }\end{array}$ & 1.00 & 1.08 & $0.035^{*}$ \\
\hline 6. & Mengalami perlakuan seks tidak wajar & 1.00 & 1.00 & \\
\hline & Skor Total & 6.07 & 6.11 & 0.444 \\
\hline
\end{tabular}

Tabel 12

Perbandingan KDRT yang Dilakukan Suami terhadap Istri dan Istri terhadap Suami menurut Kabupaten

\begin{tabular}{|c|c|c|c|c|}
\hline \multirow[b]{2}{*}{ No } & \multirow[b]{2}{*}{ Kekerasan dalam Rumahtangga } & \multicolumn{2}{|c|}{ Rataan } & \multirow[b]{2}{*}{ T-test } \\
\hline & & $\begin{array}{l}\text { Cianjur } \\
(\mathbf{N}=\mathbf{8 8})\end{array}$ & $\begin{array}{c}\text { Indramayu } \\
(\mathbf{N}=90)\end{array}$ & \\
\hline 1. & Suami terhadap istri & 45.24 & 46.30 & 0.669 \\
\hline 2. & Istri terhadap suami & 45.18 & 45.38 & $0.039 *$ \\
\hline
\end{tabular}

Tabel 13

Perbandingan KDRT Suami terhadap Istri dan Istri kepada Suami menurut Jenis Kelamin

\begin{tabular}{llccc}
\hline \multirow{2}{*}{ No } & \multirow{2}{*}{ Kekerasan dalam Rumahtangga } & \multicolumn{2}{c}{ Rataan } & T-test \\
\cline { 3 - 4 } & & $\begin{array}{c}\text { Laki-laki } \\
(\mathbf{N = 1 7 8 )}\end{array}$ & $\begin{array}{c}\text { Perempuan } \\
(\mathbf{N = 1 7 8 )}\end{array}$ \\
\hline 1. & Suami terhadap istri & 46.07 & 45.49 & 0.263 \\
\hline 2. & Istri terhadap suami & 45.39 & 45.18 & 0.649 \\
\hline
\end{tabular}

Ket.: Ket.: Ket.: Ket.: $1=$ Tidak pernah, $2=$ Kurang dari 2 kali dalam sebulan, 3=3-4 kali dalam sebulan, $4=$ Lebih dari empat kali dalam sebulan $* p \leq 0.05=$ berbeda nyata

yang meliputi kekerasan fisik, psikis, seksual, sosial, dan ekonomi. Hasil tersebut juga didukung dari hasil penelitian yang dilakukan oleh Ayesha (2012: 59) dan Fauziani (2012: 72).

Meskipun demikian, ketiga penelitian tersebut memiliki perbedaan dari proporsi kekerasan terbesar yang dirasakan istri. Penelitian yang dilakukan oleh Mutiarawana (2010:65) di daerah Bogor lebih banyak mengalami kekerasan fisik dan psikis atau sosial. Sementara itu, penelitian Ayesha (2012: 61) di daerah Subang, kekerasan yang banyak dialami oleh istri yaitu kekerasan fisik dan ekonomi. Selain itu, dari penelitian Fauziani (2012: 75) menunjukkan adanya kekerasan verbal yang dilakukan oleh ibu mertua terhadap istri.

Hasil observasi dan wawancara dengan 20 orang informan di lokasi penelitian, 
menunjukkan bahwa penyebab terbesar dari KDRT adalah kondisi keluarga atau kondisi internal, antara lain orangtua suka memukul, ayah tidak peduli dan tidak di rumah. Penyebab lainnya adalah penyebab non psikis, yaitu ibu menjadi TKI, putus sekolah dan terpaksa bekerja.

Data tersebut menunjukkan bahwa penyebab utama KDRT adalah ketidakharmonisan keluarga yang terjadi karena desakan faktor luar seperti kebutuhan ekonomi, ketiadaan pencari nafkah, perceraian maupun perilaku negatif orangtua yang memang senang melakukan kekerasan. Ketidakharmonisan keluarga ini memaksa anak menerima pengasuhan dari keluarga besarnya yang memiliki nilai dan norma asuh yang berbeda dengan pola asuh dari orang tua kandung. Eksploitasi orang tua terhadap anak, mental bekerja mencari uang juga menjadi salah satu potensi KDRT.

Mengingat permasalahan sosial yang kompleks terkait dengan fenomena KDRT, baik oleh pihak suami maupun istri, dimana mereka pada umumnya hanya memiliki kapasitas pengelolaan keluarga yang terbatas, karena tergolong keluarga miskin sehingga dalam menjalankan fungsi keluarga juga belum optimal.

Oleh karena itu, pemberdayaan keluarga di tingkat komunitas menjadi titik awal yang penting untuk meningkatkan kapasitas keluarga dalam menjalankan fungsi-fungsinya. Salah satu kelembagaan lokal pemberdaya keluarga yang handal adalah Pos Pemberdayaan Keluarga (Posdaya). Kelembagaan ini cukup potensial dikembangkan menjadi wadah koordinasi kegiatan penguatan fungsi-fungsi keluarga secara terpadu pada komunitas tertentu. Di Indonesia, saat ini terdapat lebih dari 40.000 Posdaya yang diinisiasi dan dikembangkan oleh masyarakat dengan dampingan perguruan tinggi, pemerintah daerah, maupun swasta (YDSM, 2015: 5).

\section{Simpulan dan Saran}

Tidak terdapat perbedaan yang nyata intensitas KDRT yang dilakukan oleh suami terhadap istri di Kabupaten Cianjur dan Indramayu, baik berupa kekerasan fisik, sosial, psikis, ekonomi, maupun seksual; namun intensitas KDRT oleh suami terhadap istri cenderung lebih tinggi terjadi di Kabupaten Indramayu. Sementara itu, terdapat perbedaan yang nyata intensitas
KDRT yang dilakukan oleh istri terhadap suami di Kabupaten Cianjur dan Indramayu, baik berupa kekerasan fisik, sosial, psikis, ekonomi maupun seksual; dimana intensitas KDRT di Kabupaten Indramayu cenderung lebih tinggi, kecuali pada intensitas kekerasan sosial dan ekonomi.

Intensitas KDRT yang dilakukan oleh pihak suami kepada isteri dan sebaliknya di Kabupaten Cianjur dan Indramayu masih termasuk dalam kategori rendah. Meskipun potensi KDRT di tingkat keluarga masih tergolong rendah, namun karena tekanan ekonomi yang cenderung meningkat, adanya perubahan gaya hidup dan pergeseran makna keluarga; maka dikuatirkan hal tersebut dapat mendorong timbulnya intensitas KDRT yang lebih tinggi pada masa mendatang.

Oleh karena itu, berdasarkan pemetaan KDRT dan faktor-faktor yang berhubungan, dapat disusun model intervensi untuk menguatkan kelembagaan lokal yang dapat mendukung perlindungan keluarga terhadap KDRT di komunitas masing-masing, misalnya melalui Posdaya (Pos Pemberdayaan Keluarga).

\section{Daftar Pustaka}

Akyüz, A., Yavan, T., Sahiner, G. and Kilic, A. (2012). "Domestic Violence and Woman's Reproductive Health: A Review of the Literature." Aggression and Violent Behavior 17: 514-518.

Astuti, S.I. (2013). "Patologi Kekerasan dalam Berita Televisi: antara kontroversi dam regulasi." MIMBAR: Jurnal Sosial dan Pembangunan 29(1): 41-48.

Ayesha, Y. (2012). Hubungan Permasalahan Kekerasan dalam Rumah Tangga (KDRT), Strategi Koping dan Tingkat Stress Istri (Kasus di Kabupaten Subang, Jawa Barat). Bogor: Institut Pertanian Bogor.

Cardoso, J.B. and Fong, R. (2010). Child Human Trafficking Victims: challenges for the child welfare system. Journal Evaluation and Program Planning 33(03): 311316. http://www.sciencedirect.com/ science/article/pii/ S0149718909000640 [Diunduh 5 Maret 2015].

Chan, Y.C. and Yeung, J.W.K. (2009). Children Living with Violence within the Family and Its Sequel: a meta-analysis from 19952006. Journal Aggression and Violent Behavior 14(05): 313-322. http://www. sciencedirect.com/ science/article/pii/ S1359178909000408 [Diunduh 5 Maret 2015].

Fachrina dan Anggraini, N. (2007). Kekerasan terhadap Perempuan dalam Keluarga pada 
Masyarakat Minangkabau Kontemporer. Artikel IImiah Penelitian Kajian Wanita. Edisi 29 Maret 2007. http://repository. unand.ac.id/3972/1/Facrina.pdf [Diunduh 6 Maret 2013].

Fauzani, M. (2012). Analisis Pertukaran Barang dan Jasa, Keharmonisan, serta Tingkat Stress antara Menantu Perempuan dan Ibu Mertua. Bogor: Institut Pertanian Bogor.

Fishel, A.H. and Rynerson, B.C. (1998). Domestic Violence and Family Interdependence. Aggression and Violent Behavior 3 (3): 295-301.

Kusantati, H. dan Widiaty, A.I. (2009). Pemberdayaan Perempuan Korban Trafficking melalui Model Based Care. Pusat Dokumentasi dan Informasi Ilmiah - Lembaga Ilmu Pengetahuan Indonesia (PDII-LPI). http://file.upi.edu/Direktori/ FPTK/JUR._PEND. KESEJAHTERAAN KELUARGA/197203071999032-ANA/ File1-artikel_fundamental_2009.pdf. [Diunduh 5 Maret 2015].

Munro. (2011). The Munro Review of Child Protection: final report A child-centred system. United Kingdom [UK]: The stationery office limited.

Mutiarawana, M. (2010). Analisis Hubungan Kekerasan dalam Rumah Tangga (KDRT) dengan Kualitas Perkawinan dan Kesejahteraan Keluarga. Bogor: Institut Pertanian Bogor.

Nasution, Z.A. (2008). Perlindungan Hukum terhadap Perempuan dan Anak Korban Perdagangan Manusia (Trafficking in Persons). http://eprints.undip.ac.id/ 17904/1/Zaky_Alkazar_Nasution.pdf [Diunduh 26 Februari 2015].

Nursanti, H. (2010). Analisis Hubungan Kekerasan pada Anak dengan Keadaan Psikologis dan Perilaku Anak, serta Kepuasan terhadap Kesejahteraan Keluarga. Bogor: Institut Pertanian Bogor.

Pawito dan Kartono, D.T. (2013). Konstruksi Identitas Kultural Masyarakat Pluralis dalam Terpaan Globalisasi. MIMBAR: Jurnal Sosial dan Pembangunan 29(1): 111-120.
Presiden Republik Indonesia. (2004). UndangUndang Republik Indonesia Nomor 23 Tahun 2004 tentang Penghapusan Kekerasan Dalam Rumah Tangga. Lembaran Negara Republik Indonesia Tahun 2004 Nomor 95.

Puspitawati, H. (2009). Kaji Tindak Model Pengentasan Kemiskinan melalui Pemberdayaan Gender dan Keluarga Berbasis Pertanian dan Keunikan Agroekosistem Pedesaan - kluster pengentasan kemiskinan. Penelitian Hibah Kompetitif, April-Desember 2009: Dirjen Dikti-Depdiknas.

Puspitawati, H., Herawati, T, Hastuti dan Trikoesoemaning. (2008). Kajian Model Pemberdayaan Keluarga Berbasis Pertanian dalam Meningkatkan Ekonomi Keluarga dan Tumbuh Kembang Anak di Kabupaten Bogor. Gender and Family, Penelitian Hibah Bersaing, 2008-2009: Dirjen Dikti-Depdiknas.

Putri, A.M. dan Santoso, A. (2012). Persepsi Orang Tua tentang Kekerasan Verbal. Jurnal Nursing Studies 01(01): 22-29. http://ejournals1.undip.ac.id/ index.php/ jnursing/ article/view/127 [Diunduh 5 Maret 2015].

Setiadi, A. (2014). Angka KDRT di Indonesia Meningkat, Ini Sebabnya. . http:// daerah.sindonews.com/ read/919676/22/ angka-kdrt-di-indonesia-meningkat-inisebabnya-1415099048 [Diunduh 11 Maret 2015].

Sutinah dan Kinasih, S.E. (2008). Tindak Kekerasan terhadap Anak Perempuan pada Saat Pemilihan Jodoh di Kalangan Etnis Arab-Surabaya: studi kasus di Ampel, Kecamatan Semampir-Surabaya. Jurnal Penelitian Dinas Sosial 07(01): 23-30. http://journal.unair.ac.id/ filerPDF/20April2008-30.pdf [Diunduh 28 Februari 2015]

Suyono, H. dan Haryanto, R. (2007). Pedoman Pembentukan dan Pengembangan Posdaya. Jakarta: Balai Pustaka.

Undang-undang Republik Indonesia Nomor 23 Tahun 2004 tentang Penghapusan Kekerasan Dalam Rumah Tangga. 